\title{
INFLUENCE OF ANTHROPOPRESSION ON CONCENTRATION OF BIOGENIC COMPOUNDS IN WATER OF SMALL PONDS IN FARMLAND
}

\author{
Małgorzata Gałczyńska, Marcin Kot \\ Chair of General and Ecological Chemistry \\ West Pomeranian University of Technology in Szczecin
}

\begin{abstract}
A rapidly diminishing number and degradation of water ponds cause many negative effects in the structure of agricultural ecosystems, by limiting surface retention and increasing migration of chemical compounds from the basin. The goal of this research was to find the influence of anthropopression on the chemical composition of water in field ponds. Analysis of some chemical and physical parameters was carried out on water samples collected once a month from 5 field ponds located in the District of Pyrzyce, Commune of Żabowo, between March and October 2004. The five water ponds differed with respect to the spatial development of their surroundings and their degradation. The concentration of $\mathrm{N}-\mathrm{NH}_{4}{ }^{+}, \mathrm{N}-\mathrm{NO}_{2}{ }^{-}$i N-NO${ }_{3}^{-}$oraz $\mathrm{PO}_{4}{ }^{3-}$ were measured according to the Polish Standards. The level of oxygen, temperature and water $\mathrm{pH}$ were measured immediately after collecting each sample of water. The analyzed field ponds were different in respect of the degree of degradation processes. What was characteristic of the five ponds was a large variation in concentrations of biogenic compounds in water, depending on the form of anthropopression and vegetation in and around the ponds. The high level of $\mathrm{PO}_{4}{ }^{3-}$ and $\mathrm{N}-\mathrm{NH}_{4}{ }^{+}$in water and the succession of water plants prove that ponds 2,3 and 4 are highly eutrophicated. Due to the extremely high concentration of $\mathrm{PO}_{4}{ }^{3-}$ in the water, field pond 2, located near a former state farm, can be classified as hypertrophic. This pond also had the biggest oxygen deficit.
\end{abstract}

Key words: nitrogen, phosphorus, mid-field water ponds.

dr inż. Małgorzata Gałczyńska, Chair of General and Ecological Chemistry, West Pomeranian University of Technology in Szczecin, ul. Słowackiego 17, 71-434 Szczecin, Poland, phone: (091)449 6322, e-mail: Malgorzata.Galczynska@zut.edu.pl 


\begin{abstract}
Abstrakt
Szybkie zanikanie i degradacja oczek wodnych pociąga za sobą wiele negatywnych zjawisk w strukturze agroekosystemów, zmniejsza retencję powierzchniową i powoduje wzrost migracji składników ze zlewni. Celem pracy było ustalenie wpływu antropopresji na skład chemiczny wód śródpolnych oczek wodnych. Materiał do analiz wybranych wskaźników chemicznych i fizycznych wód stanowiły próbki wodne pobierane raz w miesiącu z 5 oczek śródpolnych położonych $\mathrm{w}$ powiecie pyrzyckim, w gminie Żabowo, w okresie od III do X 2004 roku. Badane zbiorniki różniły się nie tylko sposobem zagospodarowania terenu w bezpośrednim ich sąsiedztwie, ale również formą dewastacji. Oznaczenia stężeń: $\mathrm{N}_{-} \mathrm{NH}_{4}^{+}$, $\mathrm{N}-\mathrm{NO}_{2}{ }^{-}$i N-NO${ }_{3}^{-}$oraz $\mathrm{PO}_{4}{ }^{3-}$ wykonano zgodnie z Polskimi Normami. W terenie, bezpośrednio po poborze prób, zmierzono stężenie tlenu, temperaturę i $\mathrm{pH}$ wód. Ustalono, że analizowane śródpolne oczka wodne różniły się stopniem zaawansowania procesów degradacji. Cechą charakterystyczną badanych obiektów była duża zmienność stężeń związków biogennych $\mathrm{w}$ wodzie zależna od formy antropopresji oraz roślinności występującej w zbiorniku i wokół niego. Wysoki poziom stężenia $\mathrm{PO}_{4}{ }^{3-} \mathrm{i} \mathrm{N}^{-\mathrm{NH}_{4}}{ }^{+} \mathrm{w}$ wodach oraz sukcesja roślinności wodnej świadczą o zaawansowanym procesie eutrofizacji szczególnie oczek $\mathrm{nr} 2,3$ i 4. Bardzo duże stężenie ortofosforanów(V) w wodach oczka $\mathrm{nr} 2$, położonego przy zabudowaniach dawnego PGR-u, można uznać za hipertroficzne. W wodach tych stwierdzono też największy deficyt tlenowy.
\end{abstract}

Słowa kluczowe: azot, fosfor, śródpolne oczka wodne.

\title{
INTRODUCTION
}

Among many different glacial forms in the area of Pomorze Szczecińskie, there are numerous water ponds, which can now be called biotope 'islands' in the otherwise monotonous agricultural landscape, but they are also part of ecological corridors for migrating animals. In agricultural areas, such closed water ecosystems are exposed to a risk of area and point contamination (e.g. illegal rubbish dumping or municipal sewage discharge). A rapid decrease in the number of ponds and their degradation cause a chain of negative changes in agroecosystems, by decreasing surface retention and increasing migration of nutrients from the basin (PIEŃKOWSKI 1996, KocHANowska, Raniszewska 1999, Koc et. al. 2001, Pieńkowski, Podlasińki 2001).

The goal of this research was to find the influence of anthropopression on the chemical composition of water in field ponds.

\section{MATERIAL AND METHODS}

Water samples taken from five field ponds in Żabowo, District of Pyrzyce, provided material for analyses of selected chemical and physical parameters. 
The ponds differed with respect of the use of their surroundings and form of degradation.

Pond 1 had highly developed water vegetation and open water surface. Around the pond there were no bushes or trees which could limit intensive transpiration from the water surface. At the time of the study, wheat was planted around the pond. A rubble dump was situated near the pond and in the pond itself food waste and used tires were seen. The general morphometric parameters of the pond are as follows: $1.2 \mathrm{~m}$ depth, $30 \mathrm{~m}^{2}$ surface square footage, $0.5 \mathrm{~m}$ depth. After five months of research the pond's water disappeared.

Pond 2 was located close to farm buildings of a former state farm. This location means that the pond had been probably used for flushing dung. Although there were many bushes growing around the pond, its water table was not shaded. The whole pond was overgrown with dense Lemna minor, which proves the hypertrophic character of the pond; rubbish and animals' bones were noticed on the surface. Canola was planted around the pond. The pond was $512 \mathrm{~m}^{2}$ in square footage. There was a 4-meter gap between the pond's border and the water surface. Water depth was $0.2-0.3 \mathrm{~m}$. The pond had a very high level of the bottom sludge.

Pond 3 differed significantly from the others because it was separated from the cultivated surface with a dense border of trees and bushes. The pond's border was situated higher than the ground level of the field. This suggested limited surface flow. Near the pond, there was an illegal rubbish dump and a rubble dump (including empty bags of fertilizers and pesticides). In the absence of plants in the water, there were only algae. The pond's surface decreased from $8 \mathrm{~m}^{2}$ to $1 \mathrm{~m}^{2}$ during the research's time. The pond's area was covered with dense bushes and trees. There was a 4-meter gap between the pond's border and the water surface.

Pond 4 was located in some fallow land, about $150 \mathrm{~m}$ from expressway E-65. Around the pond there were trees and bushes, which shaded the water's surface. Lack of water plants was characteristic for this pond. Used car tires and plastic bags were seen in the water. General morphometric parameters of the pond: long shape, $18 \mathrm{~m}$ length, $3 \mathrm{~m}$ depth, $3.5 \mathrm{~m}$ width. There was water at the pond's bottom, which disappeared after four months of the research.

Pond 5 was located on the outskirts of the village of Ryszewko. There was a road, some houses, a milk collection site (closed at the time) and farmland in its close neighborhood. This pond had the highest water potential among all the examined ponds. There was a large number of algae in water and a broad belt of Phragmites australis covering $20 \%$ of the surface. The surface square footage was $372 \mathrm{~m}^{2}$ and the water depth was $0.5-1.0 \mathrm{~m}$.

Water samples for chemical and physical analyses were collected once a month. The tests were carried out from March to October 2004. Chemical determinations of $\mathrm{N}$ and $\mathrm{P}$ were obtained by colorimetry. In water samples, 
concentrations of ammonium nitrogen, nitrite nitrogen, nitrate nitrogen and orthophosphates were measured according to the Polish Standards (PN-76/ /C-04576.01, PN-73/C-04576.06, PN-82/C-04576.08, PN-EN 1189:2000). Immediately after taking the samples, oxygen concentration, temperature and water $\mathrm{pH}$ were measured. All measurements were repeated three times.

\section{RESULTS AND DISCUSSION}

The analyzed parameters of water (Table 1) were different depending on dates of sample collection and pond location.

The average water temperature was $13.9^{\circ} \mathrm{C}$, which on the one hand was good for dissolution of chemical compounds and growth of water organisms, but on the other hand contributed to the depletion of oxygen in water. In ponds 3 and 4, the temperature of water was lower than in the other ponds because of the shadow cast by trees and bushes. Very shallow waters tend to warm up and cool down fast, depending on the term of the year and insolation.

Higher variation of the results was found in the analysis of oxygen's concentration in the water. The average results for each pond were higher than those measured by Skwierawski and Szyperek (2002) for twenty ponds (4.0-6.8 $\mathrm{mg} \mathrm{O}_{2} \cdot \mathrm{dm}^{-3}$ ). In pond 2, oxygen deficit was noticed (less than 2-3 $\mathrm{mg} \mathrm{O} \mathrm{O}_{2} \cdot \mathrm{dm}^{-3}$ ), caused by degradation of organic compounds with the use of oxygen, which occurred in water and in bottom sediments. Moreover, dense Lemna minor covering the whole water surface limited water surface movements and, in consequence, oxygen diffusion.

The reaction of water in the examined ponds was slightly acidic or neutral, between $\mathrm{pH} 6.4$ and 7.1. The results are significantly lower than the average results measured by SkwiERAWSKI and SzYPEREK (2002), who determined $\mathrm{pH} 7.06$ for waters in farmland, $\mathrm{pH} 7.29$ for fallow land, $\mathrm{pH} 7.76$ for build-up areas and $\mathrm{pH} 6.97$ for forests. It was also noticed that the highest $\mathrm{pH}$ values are measured in spring, after which they gradually decrease to reach the spring values in autumn. This, however, is more of a general tendency as in some ponds the water $\mathrm{pH}$ was unstable.

Non-organic nitrogen in the ponds could have originated from mineral and organic fertilizers flushing from the fields, from degradation of organic compounds (food waste) and from empty bags of fertilizers.

For each pond, the average values of nitrogen ammonium significantly differed from those measured by Koc et al. (2001). The average concentration of $\mathrm{N}-\mathrm{NH}_{4}{ }^{+}$was $0.661 \mathrm{mg} \cdot \mathrm{dm}^{-3}$ (range $0.23-1.12$ ) for ponds on farmlands, $0.560 \mathrm{mg} \cdot \mathrm{dm}^{-3}(0.22-1.66)$ for build-up areas, and $0.886 \mathrm{mg} \cdot \mathrm{dm}^{-3}$ (0.34-1.26) for forests. According to SkwIERAWSKI and SzYPEREK (2002), the average value of $\mathrm{N}^{-\mathrm{NH}_{4}}{ }^{+}$for ponds located on farmland was $0.58 \mathrm{mg} \cdot \mathrm{dm}^{-3}$, 
Table 1

Chemical and physical proporties of the investigated waters in 2004

\begin{tabular}{|c|c|c|c|c|c|c|c|}
\hline \multicolumn{2}{|c|}{ No. mid-field ponds } & 1 & 2 & 3 & 4 & 5 & $1 \div 5$ \\
\hline $\begin{array}{l}\mathrm{N}-\mathrm{NH}_{4}^{+} \\
\mathrm{mg} \cdot \mathrm{dm}^{-3}\end{array}$ & mean & 0.27 & 1.88 & 0.94 & 2.33 & 0.39 & $\begin{array}{c}1.16 \\
\text { SD } 1.44\end{array}$ \\
\hline $\begin{array}{l}\mathrm{N}-\mathrm{NO}_{2}^{-} \\
\mathrm{mg} \cdot \mathrm{dm}^{-3}\end{array}$ & mean & 0.003 & 0.019 & 0.012 & 0.039 & 0.023 & $\begin{array}{c}0.019 \\
\text { SD } 0.026\end{array}$ \\
\hline $\begin{array}{l}\mathrm{N}-\mathrm{NO}_{3}{ }^{-} \\
\mathrm{mg} \cdot \mathrm{dm}^{-3}\end{array}$ & mean & 0.24 & 0.40 & 0.41 & 0.96 & 0.14 & $\begin{array}{c}0.43 \\
\text { SD } 0.38\end{array}$ \\
\hline $\begin{array}{c}\mathrm{PO}_{4}^{3-} \\
\mathrm{mg} \cdot \cdot \mathrm{dm}^{-3}\end{array}$ & mean & 0.4 & 84.2 & 1.0 & 1.0 & 1.1 & $\begin{array}{c}17.6 \\
\text { SD } 17.4\end{array}$ \\
\hline $\begin{array}{c}\mathrm{mg} \\
\mathrm{O}_{2} \cdot \mathrm{dm}^{-3}\end{array}$ & mean & 5.1 & 2.5 & 7.1 & 5.1 & 6.0 & $\begin{array}{c}5.2 \\
\text { SD } 2.0 \\
\end{array}$ \\
\hline $\begin{array}{l}\text { Temp. } \\
{ }^{\circ} \mathrm{C}\end{array}$ & mean & 14.1 & 16.2 & 12.9 & 12.1 & 14.3 & $\begin{array}{c}13.9 \\
\text { SD } 4.3\end{array}$ \\
\hline $\mathrm{pH}$ & mean & 7.0 & 6.9 & 7.1 & 6.4 & 7.0 & $\begin{array}{c}6.9 \\
\text { SD } 0.5\end{array}$ \\
\hline \multicolumn{2}{|c|}{ Number of sampling } & 5 & 8 & 8 & 4 & 8 & 33 \\
\hline
\end{tabular}

$0.54 \mathrm{mg} \cdot \mathrm{dm}^{-3}$ for build-up areas and $0.81 \mathrm{mg} \cdot \mathrm{dm}^{-3}$ for forests. The following aspects affected the value of $\mathrm{N}^{-\mathrm{NH}_{4}}{ }^{+}$concentration in the examined water ponds (Figure 1): oxygen conditions, temperature and growth stage of water plants. In the ponds where highly developed water plants prevailed, nitrogen ammonium ions reached concentration higher than $1 \mathrm{mg} \cdot \mathrm{dm}^{-3}$. High concentration of nitrogen ammonium ions in waters of pond 2 was caused by a large amount of organic compounds and low concentration of oxygen in the water. In pond 4 , the concentration of $\mathrm{N}^{-\mathrm{NH}_{4}}{ }^{+}$measured in June reached $6.82 \mathrm{mg} \cdot \mathrm{dm}^{-3}$, which was probably caused by a lower level of water and the presence of wild animals in the pond. In pond 1 (which dried out in July), no growth in the concentration of nitrogen ammonium ions was noticed after the disappearance of water because water plants restricted the concentration of this form of nitrogen during the time of the research. In pond 5, a low concentration of ammonium ions was observed. Among all the ponds, this one contained most water, so its ability to overcome possible contamination was the highest. The extensive area of Phragmites australis limited the biogenic content in the pond, as can become a 'filter' for possible contaminants (Koc, SzYPEREK, 2001). KochANOWSKA and RANISZEWSKA (1999) point out that lack of plant buffer around a water pond causes loss of nutrients in surface soil, from which they are flushed with water to the pond. The wide and dense belt of trees and bushes near pond $3 \mathrm{had}$ a good influence on the pond by limiting the concentration of nitrogen ammonium ions, despite the fact that empty mineral fertilizer bags were present in the pond. 


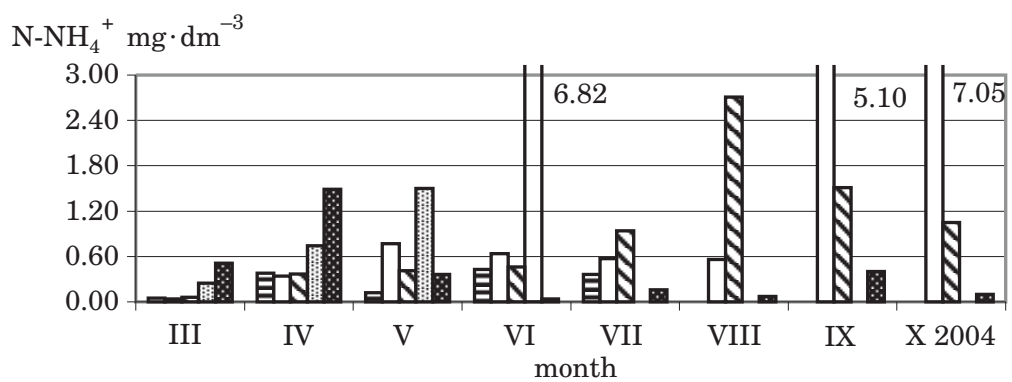

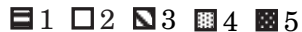

Fig. 1. Changes in the content of $\mathrm{N}^{-\mathrm{NH}_{4}}{ }^{+}$in water of mid-field ponds during the vegetation season in 2004

Nitrogen nitrate in soil and as well in water takes part in biological sorption only. Thus, it can be immobilized in the water environment, being good nourishment for the growth and development of biomass of different organisms, especially plants. The smallest average concentration of nitrogen nitrate was measured in the water of pond 5 , followed by pond 1 , and then ponds 2 and 3; the highest value was measured in pond 4 (Table 1). The average values of nitrogen nitrate concentrations measured in this research were close to those reported by Koc et al. (2001), which were $0.201 \mathrm{mg} \cdot \mathrm{dm}^{-3}$ (range 0.007-0.431) for water ponds on farmlands, $0.697 \mathrm{mg} \cdot \mathrm{dm}^{-3}(0.005$ $-2.430)$ for rough grazing meadows and $0.182 \mathrm{mg} \cdot \mathrm{dm}^{-3}(0.006-0.670)$ for buildup areas. SKWIERAWSKI and SZYPEREK (2002) measured slightly smaller concentrations of nitrogen nitrate for ponds of in the Olsztyn Lake District: $0.41 \mathrm{mg} \cdot \mathrm{dm}^{-3}$ for farmlands, $0.16 \mathrm{mg} \cdot \mathrm{dm}^{-3}$ for rough grazing meadows, $0.12 \mathrm{mg} \cdot \mathrm{dm}^{-3}$ for wasteland, and $0.25 \mathrm{mg} \cdot \mathrm{dm}^{-3}$ for build-up areas. The highest nitrogen nitrate concentration was observed in pond 5 in March, after which it decreased rapidly (Figure 2). The decrease in its concentration was caused by increased photosynthesis, growth and development of water plants and change in dissolved oxygen concentration in the water. In pond 1 , on the last sampling date, no increase of nitrogen nitrate concentration was noticed although the level of water was lower. It was also associated with absorption of this form of nitrogen by water plants. In general, it is thought that during the time of vegetation the level of $\mathrm{N}^{-\mathrm{NO}_{3}}{ }^{-}$in water declines to rise in the winter. A similar pattern was noticed for ponds 2 and 3 , where Lemna minor along with trees and bushes contributed to the reduction of the $\mathrm{N}^{-\mathrm{NO}_{3}}{ }^{-}$concentration. Such correlation can be distorted by an influx of sewage, containing high quantities of nitrogen compounds. In the water of pond 4 , a very high concentration of nitrogen nitrate was measured in the last month of water sampling (June), attributed to the lowering of the water level. An increase of this form of nitrogen was observed in most of the ponds between March and May 2004, which was probably caused by the surface flow from farmland due to intensive precipitation. 


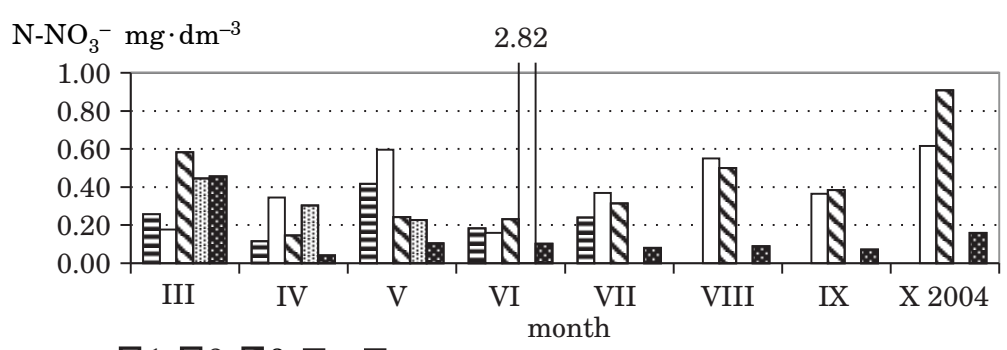

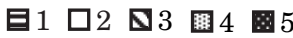

Fig. 2. Changes in the content of $\mathrm{N}^{-\mathrm{NO}_{3}}{ }_{3}^{-}$in water of mid-field ponds during the vegetation season in 2004

Nitrogen nitrite is a transitory form in a complex biochemical process of organic nitrogen transformation and its formation depends on accessibility to oxygen and on the number of nitrobacteria. For oxidation of $1 \mathrm{~g}$ of $\mathrm{N}$, $4.6 \mathrm{~g}$ of $\mathrm{O}_{2}$ is needed, which is possible only when water is properly oxygenated. The average values of nitrogen nitrite for the examined ponds (Table 1) are very similar to those measured by SkwIERAwski and Szyperen (2002) in field ponds in Olsztyn Lake District: $0.010 \mathrm{mg} \mathrm{N}-\mathrm{NO}_{2}{ }^{-} \cdot \mathrm{dm}^{-3}$ for water ponds on farmlands and $0.025 \mathrm{mg} \mathrm{N}-\mathrm{NO}_{2}{ }^{-} \cdot \mathrm{dm}^{-3}$ for ponds in build-up areas. Koc et al. (2001) measured average annual concentrations: $0.009 \mathrm{mg} \mathrm{N}-\mathrm{NO}_{2}{ }^{-}$ $\cdot \mathrm{dm}^{-3}$ (range 0.004-0.018) for water ponds on farmlands and $0.020 \mathrm{mg}$ $\mathrm{N}-\mathrm{NO}_{2}{ }^{-} \cdot \mathrm{dm}^{-3}$ (range $0.003-0.095$ ) for build-up areas. The highest concentration of nitrogen nitrite was found in pond 4 in June 2004 (Figure 3), which reflects the high levels of other forms of nitrogen discussed before $(0.138 \mathrm{mg}$ $\mathrm{N}-\mathrm{NO}_{2}{ }^{-} \cdot \mathrm{dm}^{-3}$ ). The causes of the observed changes are the same. In pond 5 , the nitrogen nitrite concentration declined five-fold from May to June and reached the value of $0.02 \mathrm{mg} \mathrm{N}-\mathrm{NO}_{2}{ }^{-} \cdot \mathrm{dm}^{-3}$, which was probably due to enhanced nitrification process because the water had the highest oxygen level. The most stable object in terms of $\mathrm{N}^{-\mathrm{NO}_{2}}{ }^{-}$concentration was pond 1 , which also contained the least of this form of nitrogen. For the water of other

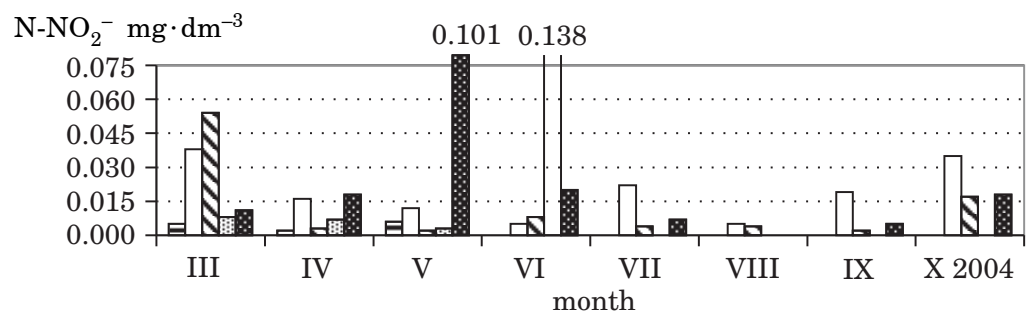

日1 $\square 2$ ③ 国 4 图 5

Fig. 3. Changes in the content of $\mathrm{N}^{-N^{-}}{ }_{2}^{-}$in water of mid-field ponds during the vegetation season in 2004 
ponds (2 and 3), the average concentration of $\mathrm{N}_{-} \mathrm{NO}_{2}{ }^{-}$was at the level of 0.012 and $0.019 \mathrm{mg} \cdot \mathrm{dm}^{-3}$, which corresponded to the measured dissolved oxygen concentrations in this water.

The analysis of the per cent shares of nitrogen forms (Figure 4) shows that nitrogen ammonium dominated in water samples taken from all of the ponds.

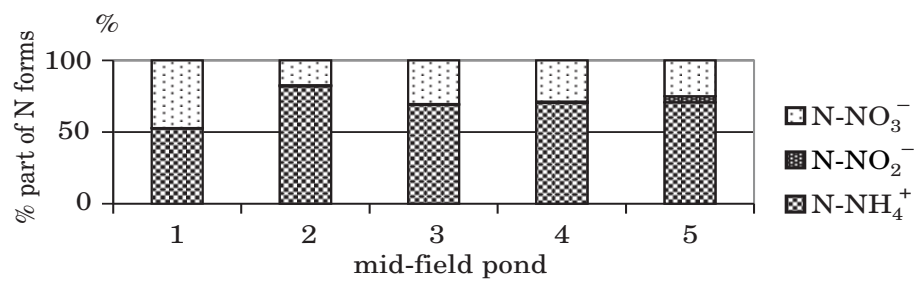

Fig. 4. Share of mineral nitrogen forms in water of mid-field ponds

Phosphorus is crucial for the growth of organisms and can be an element limiting the primary production of surface water. In the water of the five analyzed ponds, flushing rainwater with mineral and organic fertilizers from the fields, decomposing organic materials (food waste) and fertilizer remains from empty bags dumped near the ponds could be possible phosphorus sources. While analyzing the results, significant differences between summer and spring sampling dates were found. The highest concentration of $\mathrm{PO}_{4}{ }^{3-}$ was noticed in pond 2 in July $2004\left(189.4 \mathrm{mg} \cdot \mathrm{dm}^{-3}\right)$. This value was a hundred-fold higher than in the other ponds (Figure 5).

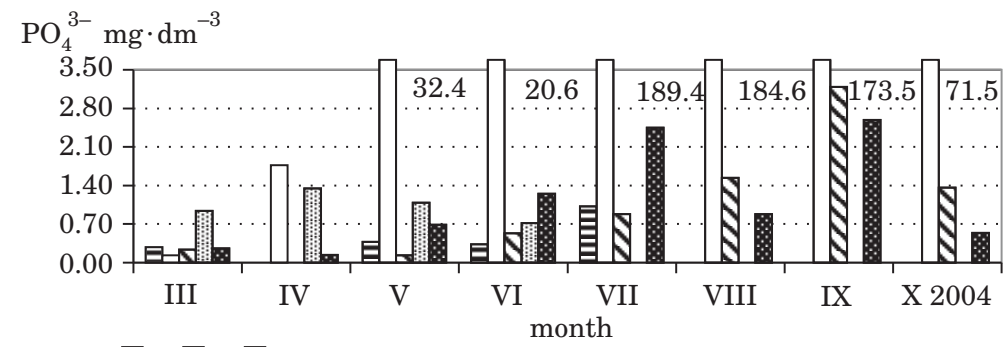

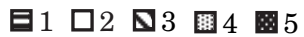

Fig. 5. Changes in the content of $\mathrm{PO}_{4}{ }^{3-}$ in water of mid-field ponds during the vegetation season in 2004

The average values of concentrations and ranges for the other ponds were higher than those measured in water of ponds in Olsztyn Lake, which is: $0.241 \mathrm{mg} \mathrm{PO}_{4}{ }^{3-} \cdot \mathrm{dm}^{-3}$ (range 0.003-0.900) for ponds on farmlands and $0.327 \mathrm{mg} \mathrm{mg} \mathrm{PO}_{4}{ }^{3-} \cdot \mathrm{dm}^{-3}$ (range $0.39-0.97$ ) for build-up areas (Koc et al. 2001). Higher values of concentrations of orthophosphates were measured 
by Durkowski and Woroniecki (2001), who examined water ponds and fish ponds located in villages of Western Pomerania, i.e. $4.796 \mathrm{mg} \mathrm{PO}{ }_{4}^{3-} \cdot \mathrm{dm}^{-3}$ (range 0.002-27.8). The upper range in that research can be compared to the results for pond 2, but is still several fold lower. According to GAŁCZYŃSKA et al. (2005), the average concentration of orthophosphates at the level of $1.7 \mathrm{mg} \mathrm{PO}_{4}{ }^{3-} \cdot \mathrm{dm}^{-3}$ was measured in the water of a field pond near Krapiel in Western Pomerania. The highest level of orthophosphates was characteristic for pond 2, located near a former state farm. This was due to a rapid decrease in the water level in summer, as well as their recirculation from the bottom sludge, which is much faster under anaerobic conditions.

The process of releasing phosphorus from bottom sludge depends on oxygen conditions, redox potential at the border of water and sludge, reaction and, to some extent, on the concentration of iron and calcium ions in sludge and in the water above it. It has to be stressed that the highest values of orthophosphates were measured in summer, and such a situation occurs in polymictic lakes, where the concentration of phosphorus in spring is usually higher than in summer due to release of this element by interstitial waters and rapid mineralization of organic material in sludge at high temperatures (Koc, Skwierawski 2004, Skwierawski 2004). Water movements in polymictyc ponds, caused by wind, make the surface part of the bottom sludge, saprophel, diffuse into water. This slime, because of its chemical content and structure, causes immediate increase of oxygen consumption and dramatically reduces water clarity. Both of these phenomena initiate self-destruction of the biocenosis of a water pond because competitiveness of macrophytes and all animals, from zooplankton to fish, immediately declines. Under such conditions, atrophy of whole plant and animal species is observable, with dead plant and animal bodies secondarily increasing the deposit of saprophel so that the vicious circle starts again. Macro-hydrophytes in ponds 1 and 5 played a crucial role in creating a dynamic exchange of phosphorus compounds between water and sludge. The average concentration of orthophosphates in the water of these ponds was 0.4 and $1.1 \mathrm{mg} \cdot \mathrm{dm}^{-3}$, respectively. On the one hand, sludge is a source of biogenic compounds for rooted plants, participating in the recycling of phosphorus accumulated in deeper layers, which theoretically are not involved in the circle, (Pieczý́sKa 1988, 1993). On the other hand, some plants rooted in the bottom cause oxygenation of the core of sludge deposits and limit water surface movements, improving conditions of sedimentation and limiting resuspension (PIECZYŃSKA 1988, WiŚNIEWSKI 1995). In the water of ponds 3 and 4 , the surrounding trees and bushes took part in reducing the concentration of orthophosphates by absorbing biogenic compounds. 


\section{CONCLUSIONS}

1. The examined field water ponds in Pyrzyce Plain (Równina Pyrzycka) differ in the processes of degradation which occurred in these water bodies.

2 . There was a large variation in the concentration of biogenic compounds in the water of the five ponds, depending on the form of athropopression and vegetation in each pond and its surroundings.

3. The high level of $\mathrm{PO}_{4}{ }^{3-}$ and $\mathrm{N}^{-} \mathrm{NH}_{4}{ }^{+}$in the water of the ponds and succession of water plants prove that water ponds 2,3 and 4 are highly eutrophicated.

4. The extremely high concentration of $\mathrm{PO}_{4}{ }^{3-}$ in the water of pond 2, located near a former state farm, can be classified as hypertrophic. This pond also demonstrated the highest oxygen deficit.

\section{REFERENCES}

Durkowski T., Woroniecki T. 2001. Jakość wód powierzchniowych obszarów wiejskich Pomorza Zachodniego [Quality of surface water in agricultural land in Western Pomerania]. Zesz. Probl. Post. Nauk Rol., 476: 365-371 (in Polish).

GAŁCZyŃSKA M., WyBIERALSKI J., SiweK H. 2005. Zawartość związków mineralnych w wodach powierzchniowych $w$ wybranych punktach terenów rolniczych województwa zachodniopomorskiego [Content of mineral compounds in surface water in selected sites in agricultural land of the Province of Western Pomerania]. Chem. Inż. Ekol., 12 (S1): 63 (in Polish).

Koc J., Cymes I., Skwierawski A., Szyperek U. 2001. Znaczenie ochrony matych zbiorników wodnych $w$ krajobrazie rolniczym [Importance of conservation of small water bodies in agricultural land]. Zesz. Probl. Nauk Rol., 476: 397-407 (in Polish).

Koc J., SzYPEREK U. 2001. Rola przybrzeżnych pasów roślinności $w$ ochronie śródpolnych oczek wodnych [Role of shoreline plant belts in conservation of field water ponds]. Zesz. Probl. Post. Nauk Rol., 477: 65-72 (in Polish).

Koc J., Skwierawski A. 2004. Fosfor $w$ wodach obszarów rolniczych [Phosphorus in farmland waters]. Pr. Nauk. AE Wrocław, 1017: 165-182 (in Polish).

Kochanowska R., RANiszewska M. 1999. Jak chronić śródpolne i śródleśne oczka wodne? [How to protect field and forest water ponds?] Prz. Przyr. 10 (3-4): 69-76 (in Polish).

Pieczyńska E. 1988. Rola makrofitów w ksztattowaniu trofii jezior [Role of macrophytes in shaping the trophy of a lake]. Wiad. Ekol., 34: 376-404 (in Polish).

PIECZYŃsKa E. 1993. Strefa litoralu a eutrofizacja jezior, ich ochrona i rekultywacja [Littoral zone versus eutrophication of lakes, lake conservation and reclamation]. Wiad. Ekol., 39 (3): 139-162 (in Polish).

Pieńkowski P. 1996. Przeksztatcenia oczek wodnych na przyktadzie pótnocnej części Równiny Wettyńskiej [Transformations of water ponds; a case study of the northern part of Wettyńska Plain]. Zesz. Nauk., 173 (63): 37-41 (in Polish).

Pieńkowski P., Podlasińki M. 2001. Podziat i geneza oczek wodnych na przyktadzie wybranych obiektów $w$ strefie moreny czotowej Pomorza Zachodniego [Division and origins of water ponds; a case study of ponds in the sphere of a frontal moraine in Western Pomerania]. Zesz. Nauk. AR Szczecin, Rol., 88: 223-230 (in Polish). 
PN-73/C-04576.06. Woda $i$ ścieki. Badania zawartości zwiazków azotu azotynowego z kwasem sulfanilowym $i$ 1-naftyloaming [Water and sewage. Analyses of the nitrite nitrogen content with sulphanilic acid and 1-naphtylamine] (in Polish).

PN-76/C-04576.01. Woda $i$ ścieki. Badania zawartości zwiq̨zów azotu amonowego metoda indofenolowa [Water and sewage. Analyses of the content of ammonia nitrogen compounds with the indophenol method] (in Polish).

PN-82/C-04576.08. Woda i ścieki. Oznaczanie azotu azotanowego metoda kolorymetryczna $z$ salicylanem sodowym [Water and sewage. Determination of nitrate nitrogen by colorimetry with salicylate (in Polish).

PN-EN 1189:2000. Water quality. Determination of phosphorus. Ammonium molybdate spectrometric method.

Skwierawski A. 2004. Akumulacja fosforu w wodzie i osadach dennych jako wskaźnik poziomu degradacji stawów wiejskich $i$ oczek śródpolnych [Accumulation of phosphorus in water and bottom sediments as an indicator of the degree of degradation of rural and field water ponds]. Pr. Nauk. AE Wrocław, 1017: 183-192 (in Polish).

Skwierawski A., SzYPEREK U. 2002. Wptyw rolnictwa na jakość wody w matych zbiornikach wodnych Pojezierza Olsztyńskiego [Effect of agriculture on quality of water in small water bodies in Olsztyn Lake District]. Fragm. Agronom., (XIX) 2 (74): 236-243 (in Polish).

WIŚNIEWSKI R. 1995. Wptyw resuspensji osadów na funkcjonowanie ekosystemów wodnych [Effect of resuspension of bottm sediments on water ecosystems]. Rozpr. UMK Torun, 85: 65 (in Polish). 